\title{
Prevalence of Helicobacter Pylori Among Clients Attending Private Medical Laboratory Diagnostic Center In Karsh, Abuja, Nigeria
}

\author{
Okezie Gabriel Chidiebere (Okezie, Gabriel. C)*, Prof. R.A.U.Nwobu*, Mgbowula Goodness Ifeoma (Mgbowula \\ Goodness.I)**
}

\begin{abstract}
*Department of Medical Laboratory Science, Faculty of Health Sciences and Technology College of Health Sciences,Nnamdi Azikiwe University, Nnewi Campus, Anambra, State, Nigeria..

** Digital Health Studies,Algonquin College.Canada.
\end{abstract}

DOI: 10.29322/IJSRP.10.11.2020.p10762

http://dx.doi.org/10.29322/IJSRP.10.11.2020.p10762

\begin{abstract}
Helicobacter pylori infection is the most common chronic bacterial infection around the world. It is a major aetiological factor in chronic gastric carcinoma and gastric mucosal associated lymphoid tissue lymphoma. A study on the prevalence of Helicobacter pylori was carried out among 204 clients comprised 118 males and 86 females aged 11- 50years between September,2019 to march,2020.Blood samples were collected from clients and analyzed to determine the presence of Helicobacter pylori using Global Device H.pylori Antibody Rapid test cassette. Out of 204 clients screened 120 (58.8\%) were positive for Helicobacter pylori. The result shows that males were more infected than females with 64(31.4\%) and 56(27.4\%) positive cases respectively. The infection varied according to age group where 31-40years age had the highest infection rate of $80(27.9 \%)$,followed by 21-30years $57(20.1 \%), 41-50$ years $12(5.9 \%)$ and age group 11-20years had the least prevalence 10(4.9\%).Distribution according to marital status shows that single had higher prevalence of 77(37.7\%) and married had the least $43(21.1 \%)$.The distribution according to sources of drinking water shows that sachet water had the highest prevalent $81(38.2 \%)$,followed by bore hole $27(14.7 \%$ ), well $10(4.9 \%)$ and pipe-borne water had the least $2(1.0 \%)$,stream/rivers had zero prevalence. There was no statistical significance relationship different between age, sex, marital status and sources of drinking water and prevalence of Helicobacter pylori infection among the clients examined. This study recorded a higher prevalence rate of Helicobacter pylori infection among clients studied strongly suggest public health enlightenment campaign on Helicobacter pylori causes and prevention should be promoted and strengthened .Good personal and environmental hygiene, provision of clean portable drinking water will significantly reduced the burden of the infection. Authors recommend the inclusion of private medical laboratory into government health policies on Helicobacter pylori.
\end{abstract}

Index Terms- Karshi, Private, Laboratory, Abuja, Medical, Helicobacter, Pylori.

\section{INTRODUCTION}

$\mathrm{H}$ elicobacter pylori (H.pylori) previously named Campylobacter pylori is a spiral, flagellated gram negative, microaerophilic bacterium found in the stomach with a capability for abundant urease production which has been implicated in several upper gastrointestinal diseases that present dyspepsis. It is a major aetiological factor in chronic gastritis, peptic ulcer disease, gastric carcinoma and gastric mucosal associated lymphoid tissue (MALT) lymphoma ([37] [44]).

Helicobacter pylori infection is the most common chronic bacterial infection around the world [23]. It causes frequently reoccurring epigastric pain or discomfort which is believed to originate in the gastric duodenal region. This may be associated with other upper gastrointestinal (GI) symptoms such as nausea, betching, vomiting, post prandial fullness, and early satiety [5].Burning abdominal pain that extends from the naval to the chest, which ranges from mild to severe. Also, changes in appetite, blood or dark stool, indigestion, weight loss .Chronic dyspeptic symptoms can be continous, intermittent (episodic) or recurrent ([20] [40]).

It has been shown at $50 \%$ of adults in developed countries and $90 \%$ of adults in developing countries were positive of serum antibodies against H.pylori [17].The critical period at which H.pylori is acquired is during childhood, especially in the developing countries and areas of overcrowding and socioeconomic deprivation [30].

Helicobacter pylori is found down the middle the number of inhabitants on the planet. Its prevalence indicates enormous topographical varieties. In different creating nations over $80 \%$ of the populace in Helicobacter pylori positive even at a youthful age [39]. The prevalence in industrialized nations by and large stages under $40 \%$ and is significantly lower in young sters and teenagers than in grown up. The predominance of H.pylori relates with financial status, specifically in connection to living conditions at young age [25].

H.pylori infection is common worldwide with prevalence rates ranging from 30 to $40 \%$ in the united states, 80 to $90 \%$ in South Africa and 70 to $90 \%$ in Africa. It is more common in developing countries and its prevalence increases with age from $20 \%$ among teenagers to 50 to $60 \%$ of subjects in the $6^{\text {th }}$ and $7^{\text {th }}$ decades of life [3] .In a hyperdemic area like Nigeria, studies by [7] in Kano reported an H.pylori prevalence of 81\%, [28] in Jos, found a prevalence of $87 \%$ while [2] reported $73 \%$ in Southwest. [22] reported $12.7 \%$ in Warri. [1] reported $64 \%$ in Ibadan. [21] 
reported 54\% in Nassarawa State, North Central. [38] reported $89.7 \%$ in Delta State South South Nigeria.

Studies from many African Countries reported similar prevalence rates of $91.7 \%$ in Egypt [14], 97\% in Gambia [41], $75.5 \%$ in Morocco [10] and 65.7\% in Ethiopia [27].

Similarly, in Asia prevalence rates of $92 \%$ have been reported in Bangladesh [4] and 62\% prevalence was found in Chinese [42].

The prevalence of H.pylori infection varies between and within Countries in relation to age, race, ethnicity and geographical area of the population [31].

Human is the main reservoir of this infection. Infected mother and older siblings are important factors for H.pylori transmission to children ([11] [17] [24]). The identified factors of increased infection risk including source of drinking water, use of pit latrine and wealth index driving transmission. These factors compiled with re-crudescence or re-infection from multiple sources accounts for the continous high prevalence of H.pylori infection in Africa [6]. Though the route of transmission of this infection is not well established, possible routes of transmission such as person-person, oval-oral and faecal-oral have been suggested.

The ability of the pathogen to survive for some days in water buttressed the fact of possible water transmission ([12] [13]).

Various diagnostic tests for H.pylori have been developed and they can be broadly classified into invasive and non-invasive tests. Invasive tests utilize endoscopic biopsy samples for histology culture, rapid urease test (RUT) and polymerase chain reaction (PCR). All these tests have been found to have sensitivity and specificity that are well above $90 \%$.The non-invasive tests do not require endoscopy. These include urea breath test (UBT), immunoglobin $G$ and $M$ serology, stool antigen test, saliva antibody test and urinary antibody test. Antibody test using either enzyme linked immune-sorbent Assay (ELISA) technique or immunochromatography test (ICT) technique ([11[26] [29] ).

\section{MATERIALS AND METHOD}

\section{STUDY AREA}

The study was carried out at Decency Amana Medical Laboratory Karshi, Abuja, Nigeria. Karshi is a satellite town situated in Abuja Municipal Area Council in Federal Capital Territory Abuja, Nigeria. Karshi geographical coordinates are $8^{\circ}$ 49' 40" North, $7^{\circ}$ 33' 0" East. Karshi is about $38 \mathrm{~km}$ to Federal capital city of Abuja and $41 \mathrm{~km}$ from Karshi to Apo. Karshi has a population of about 30,000 people. The predominant tribe in Karshi is Gwandaras who constitute about $85 \%$ of the total population. Other minority tribes in Karshi are Gade,Gbagyi,Hausa,Fulani,Igbo,Idoma,andTiv ([32] [48] [49]).

\section{STUDY POPULATION}

The study was carried out among 204 clients between the aged 11 and 50years attending Decency Amana Medical Laboratory Karshi Abuja. The study was carried out between September, 2019 and March, 2020.

\section{QUESTIONNAIRE}

This publication is licensed under Creative Commons Attribution CC BY http://dx.doi.org/10.29322/IJSRP.10.11.2020.p10762
The structured questionnaires were administered to consenting clients to obtained information on the age, gender, sources of drinking water and marital status prior to sample collection.

\section{ETHICAL APPROVAL}

Ethical approval informed consent was obtained from all the recruited clients. We obtained permission to carry out the study from the management of the Private Medical Laboratory.

\section{SAMPLE COLLECTION}

2 milliliters $(2 \mathrm{ml})$ of blood sample was drawn from each client aseptically by venipuncture and dispensed into sterile labeled anticoagulant free containers.

\section{LABORATORY ANALYSIS}

The Blood samples were centrifuged at 3000rpm for 5minutes and the serum was collected for H.pylori test. Serum Anti-Helicobacter pylori Antibody was detected using a one-step H.pylori anti-body Rapid test cassette supplied by Global Device Biotech Co Ltd, China, according to the manufacturer instructions. The cassette were labeled with sample code for easy identification. Pastures pipette was used to drop about 2 drop of serum on the cassette chamber and allowed for about 3-5minute.The result is interpreted as the presence of two color bands (Test-T band and Control $\mathrm{C}$ band) within the result window regardless of which band appeared first indicated a positive result. The presence of only one pink color band within the result window indicated a negative result. The test was invalid if control line fail to appear or no distinct color line visible in both the test and control region.

\section{STATISTICAL ANALYSIS}

Chi square test was used to determine the level of significant between age, gender, educational background and marital status. $\mathrm{P}$ value $<0.05$ was considered significant at $95 \%$ confidence interval.

\section{RESULT}

This study showed that out of the 204 clients tested the overall prevalence of Helicobacter pylori was $120(58.8 \%)$. The distribution among the clients based on gender showed that male had the highest prevalence of $64(31.4 \%)$ and female $56(27.4 \%)$.Although the difference is not statistically significant association between sexes Table.1.

The distribution of Helicobacter pylori based on the age showed that high prevalence of $57(27.9 \%)$ was recorded among the age group 31-40years, followed by 21-30years, 41(20.1\%) 4150years and 11-20years had the least prevalence 10(4.9\%). The result shows that there is no statistically significant relationship between the prevalence and age group Table. 2 .

The distribution of Helicobacter pylori according to marital status, the highest prevalence was recorded among the single individual $77(37.7 \%)$ and married had the least prevalence $43(21.1 \%)$. There was no statistical significant difference between the marital status in relation to Helicobacter pylori infection Table.3.

The distribution of Helicobacter pylori in relation to sources of drinking water by the client sampled. Those that used 
sachet water had the highest prevalence rate $78(38.2 \%)$, followed by borehole water $30(14.7 \%)$, well water $10(4.9 \%)$, pipe borne water had the least prevalence $2(1.0 \%)$ and rivers/stream recorded zero prevalence of infection Table.4.

Table.1.Distribution of Helicobacter pylori Prevalence in relation to Gender

\begin{tabular}{|l|l|l|l|l|}
\hline S. No & Gender & $\begin{array}{l}\text { No. } \\
\text { Examined }\end{array}$ & $\begin{array}{l}\text { No. } \\
\text { Positive }\end{array}$ & $\begin{array}{l}\text { Positive } \\
(\%)\end{array}$ \\
\hline 1 & Male & 118 & 64 & 31.4 \\
\hline 2 & Female & 86 & 56 & 27.4 \\
\hline 3 & Total & 204 & 120 & 58.8 \\
\hline
\end{tabular}

$\mathrm{P}$ - value $<0.05$ was considered as significant. $\mathrm{P}$-value $=0.732$

Table.2.Distribution of Helicobacter pylori Prevalence based on Age

\begin{tabular}{|l|l|l|l|l|}
\hline S. No & Age & $\begin{array}{l}\text { No. } \\
\text { Examined }\end{array}$ & $\begin{array}{l}\text { No. } \\
\text { Positive }\end{array}$ & $\begin{array}{l}\text { Positive } \\
(\%)\end{array}$ \\
\hline 1 & $11-20$ & 29 & 10 & 4.9 \\
\hline 2 & $21-30$ & 65 & 41 & 20.1 \\
\hline 3 & $31-40$ & 80 & 57 & 27.9 \\
\hline 4 & $41-50$ & 30 & 12 & 5.9 \\
\hline 5 & Total & 204 & 120 & 58.8 \\
\hline
\end{tabular}

P-value $<0.05$ was considered as significant,-value $=0.307$

\section{Table.3.Distribution of Helicobacter pylori in relation to marital status}

\begin{tabular}{|l|l|l|l|l|}
\hline S. No & $\begin{array}{l}\text { Marital } \\
\text { Status }\end{array}$ & $\begin{array}{l}\text { No. } \\
\text { Examined }\end{array}$ & $\begin{array}{l}\text { No. } \\
\text { Positive }\end{array}$ & $\begin{array}{l}\text { Positive } \\
(\%)\end{array}$ \\
\hline 1 & Single & 130 & 77 & 37.7 \\
\hline 2 & Married & 74 & 43 & 21.1 \\
\hline 3 & Total & 204 & 120 & 58.8 \\
\hline
\end{tabular}

P-value $<0.05$ was considered as significant, P-value $=0.997$

\section{Table.4.Distribution of Prevalence according to Source of} drinking water

\begin{tabular}{|l|l|l|l|l|}
\hline $\begin{array}{l}\text { S. } \\
\text { No }\end{array}$ & $\begin{array}{l}\text { Source of } \\
\text { Drinking } \\
\text { Water }\end{array}$ & $\begin{array}{l}\text { No. } \\
\text { Examined }\end{array}$ & $\begin{array}{l}\text { No. } \\
\text { Positive }\end{array}$ & $\begin{array}{l}\text { Positive } \\
(\%)\end{array}$ \\
\hline 1 & $\begin{array}{l}\text { Tap(Pipe } \\
\text { borne) }\end{array}$ & 7 & 2 & 1.0 \\
\hline 2 & Borehole & 50 & 27 & 14.7 \\
\hline 3 & Well & 26 & 10 & 4.9 \\
\hline 4 & Sachet water & 121 & 81 & 38.2 \\
\hline 5 & Rivers/Stream & 0 & 0 & 0 \\
\hline 6 & Total & 204 & 120 & 58.8 \\
\hline
\end{tabular}

$\mathrm{P}$-value $<0.05$ was considered as significant. P-value $=0.000$

\section{DISCUSSION}

This findings revealed that out of the 204 clients tested $120(58.8 \%)$ were positive for Helicobacter pylori infection. The prevalence of $58.8 \%$ in this study was lower than the $73.6 \%$ reported by [46] among patient in Zaria Metropolis, 93.3\% reported by [47] among peptic ulceratic patients in Kano.80.4\% reported by [34] in Kaduna, 93.6\% reported by [36] among dyspeptic patients that underwent gastroscopy in Maiduguri North west ,Nigeria.84.2\% by [8], $71.7 \%$ by [5], Portugal and China. This report is also lower $73.9 \%$ in Pakistan [16] and reports of findings from other African Countries which have $74.8 \%$ Ghana, Kenya (71\%) and Ethiopia 72\% ([6] [43] [45]).

This is similar to the $58 \%$ obtained by [35] in Orlu, Imo State among duodenal and gastric ulcer patients, 51.4\% reported by [11], $51.96 \%$ by [18].

This report is higher than $12.7 \%$ reported by [22] in Warri, Nigeria, 28.0\% reported by [15] among undergraduate in IlishanRemo Nigeria. The difference could be explained as a result of difference in environmental factors that can, in turn lead to differences in transmission.

The prevalence of Helicobacter pylori infection with respect to gender was found high in male $64(31.4 \%)$ than the female $5(27.4 \%)$. There was no statistical significant between the sexes. This finding is in consistent with the finding of [18].

This disagreed with [22], and [11]; [15] and [46] who observed that H.pylori infection was higher in the females than males. This shows that sex is not a risk factor.

In relation to age high prevalence of $57(27.9 \%)$ was recorded among age group of 31-40years,followed by 21-30years $41(20.1 \%)$ and while those between 11-20years had the least prevalence rate of $10(4.9 \%)$. These findings disagreed with the report of [15] who reported that between the ages 21-25years had a greater prevalence and [18] who reported that higher among 5059 years. There is no significant statistical different age group and prevalence.

Prevalence according to marital status, there was high prevalence of Helicobacter pylori among single $(37.7 \%)$ than the married $(21.1 \%)$. There is no statistically difference between marital status and prevalence. This agreed with [15] who indicates prevalence in the single than the married. This may implies that marital status is not really a risk factor for Helicobacter pylori infection.

The distribution of Helicobacter pylori in relation to sources of drinking water shows that high infection rate recorded on sachet water $(38.2 \%)$,followed by borehole water $(14.7 \%)$ and pipe borne water had the least prevalence $(1.0 \%)$.Stream/Rivers had zero prevalence. There is no statistical significant relationship.

This agreed with the findings of [11] that majority of the participants that are H.pylori positive consume sachet water and borehole water which could be contaminated as a result of improper processing of the sachets water, contamination by water vendors or inadequate drinking of the boreholes also more likelihood of fecal contamination of well, contrary to [46] who reported borehole with the highest prevalence.

Contrary to report of [9]who reported higher prevalence of H.pylori infection among subjects that sourced their drinking water from wells, stream and ponds when compared to those who use pipe-borne water.

Also, a similar study in Nigeria showed that sourcing water from well and borehole confers a higher risk of H.pylori infection the pipe-borne water [22]. Another study by [33] from Kazakhstan found high prevalence of H.pylori infection among subjects who use the river and well water for drinking compared 
to those who use tap water. In another study [19] found antiH.pylori antibody in surface and shallow ground water samples tested in the USA and concluded that the route of transmission for H.pylori is also waterborne.

\section{CONCLUSION}

This study recorded a higher prevalence rate of Helicobacter pylori infection among clients Attending Private Medical Laboratory in Karshi Abuja, Nigeria. It recommended the reduction in Helicobacter pylori infection could be achieved by public health enlightenment campaign on Helicobacter pylori causes and prevention should be promoted and strengthened. Provision of clean portable drinking water will significantly reduce the burden of the infection. An integrated approach involving all stakeholders on health should be adapted with inclusion of private medical laboratory into government health policies on Helicobacter pylori.

\section{ACKNOWLEDGEMENT}

The Authors wish to acknowledge the permission and assistance of the management and staff of Decency Amana Medical Laboratory, Karshi, Abuja, Nigeria.

\section{REFERENCES}

[1] Abiodun CJ, Otegbay J, Samuel OO, Olayiwola AO ,Adegboyega A," Prevalence of helicobacter pylori among Nigerian patients with dyspepsia in Ibadan”. Pan African Medical Journal, vol, 6(18), 2010, pp.1-2.

[2] Aboderin OA, Abdu AR, Odetoyin B, Okeke IN, Lawal OO, Ndububa DA., et al," Antibiotic resistance of Helicobacter pylori from patients in Ile -Ife, South-west, Nigeria". Africa Health Science, 2007;7:143-147.

[3] Adeniyi BA, Otegbayo JA, Lowell TO, Oluwasola AO, Odaibo,G.N.,et al, "Prevalence of Helicobacter pylori infection among Dyspepsia Patients in Ibadan, African Journal of Microbiology Research, 6(14),2012,pp.339-343.

[4] Ahmad MM, Rahman M, Rumi AK, Islam S, Huq F, Chowdhury MF., et a, "Prevalence of Helicobacter pylori in asymptomatic population A pilot serological study in Bangladesh". Journal of Epidemiology ;7, 1997, pp.251-4.

[5] Al'Faleh FZ, Ali S, Aljebreen AM, Alhammad E, Abdo AA, "Seroprevalence Rates of Helicobacter pylori and Viral Hepatitis A among Adolescents in Three Regions of the Kingdom of Saudi Arabia: is there any correlation? Helicobacter ,15(6), 2010,532-535.

[6] Archampong TN, Asmah RH, Wiredu EK, Gyasi RK, Nkrumah KN, Rajakumar K, " Epidemiology of Helicobacter pylori infection in dyspeptic Ghanaian patients. Pan Africa Medical Journal, 20, 2015, 178 [PMID: 26430475 DOI: 10.11604/pamj.2015.20.178.5024].

[7] Bashir MT, Ali BU, "Peptic ulcer disease and Helicobacter pylori infection at Kano, Nigeria. Internet Journal Gastroenterology ;8,2009, pp.1-3

[8] Bastos J, Peleteiro B, Barros R,(2013). "Socio demographic Determinants of Prevalence and Incidence of Helicobacter pylori Infection in Portuguese adults". Helicobacter, 18(6), 2013, pp.413-422.

[9] Bello AK, Umar AB, Borodo MM, "Prevalence and risk factors for Helicobacter pylori infection in gastro duodenal diseases in Kano, Nigeria". Africa Journal of Medical and Health Science, 17, 2018, pp.41-6.

[10] Benajah DA, Lahbabi M, Alaoui S, El Rhazi K, El Abkari M, Nejjari C, Amarti A, Bennani B, Mahmoud M , Ibrahimi, SA, "Prevalence of Helicobacter pylori and its recurrence after successful eradication in a developing nation (Morocco)". Clinical Research Hepatology Gastroenterology ,37, 2013, PP.519- 26.
[11] Chukwuma OM, Chukwuma GO, Manafa PO, Akulue JC, Jeremiah Z, "Prevalence and Possible Risk Factors for Helicobacter pylori Seropositivity among Peptic Ulcerative Individuals in Nnewi Nigeria". A BioMed Research Journal BMRJ, 4(1), 2020, pp.166-172.

[12] Dube C, Tanih NF, Ndip RN, "Helicobacter pylori in water sources: A global environmental health concern". Rev Environmental Health, 24,2009, pp. 1-14 [PMID: 19476289 DOI: 10.1515/REVEH.2009.24.1.1]

[13] Dube C, Tanih NF, Clarke AM, Mkwetshana N, Green E, Ndip RN.(2009). Helicobacter pylori infection and transmission in Africa: Household hygiene and water sources are plausible factor exacerbating spread. Africa Journal Biotechnology, 8,2008, pp. 6028-6035 [DOI: 10.5897/AJB09.824

[14] El Dine SS, Mubarak M, Salama R, El Raziky M, El Sherbily E, Zakzria S, et al, " Low Seroprevalence of anti- CagA antibodies inspite of high seroprevalence of anti- $\mathrm{H}$ pylori antibodies in rural Egyptian community". Research Journal of Medical Science, 3, 2008, pp.118-123.

[15] Enitan SS, Ochei JO, Akele YR, Faloye TG, Adeniyi LO, et al, "|Screening for Helicobacter Pylori Infection among Undergraduate Students of a Tertiary Institution using serum Antibody and Stool Antigen Detection Methods". Biomedical Journal of Science \&Technology Research 3(2)2018. BJSTR.MS.ID.000883.DOI: 10.26717/BJSTR.2018.03.000883

[16] Farhat N, Saqib M, Salim Afzal Syed, A A, "Frequency of seropositivity of Helicobacter pylori in patients presenting with dyspepsia". Journal of Ayub Medical College, Abbottabad, 25, 2013, pp.3-4.

[17] Fozieh JM, Tahereh N, Mansour A ," Antibacterial activity of garlic (Allium sativum) on multidrug resistance Helicobacter pylori isolated from gastric biopsies". International Journal of Enteric Pathogen, 2, 2014, pp. 16749.

[18] Gide S, Ibrahim Y, Anas G, Alegbe SD.(2019)." Prevalence of Helicobacter pylori Infection in Patients with Dyspeptic Symptoms in Damaturu Metropolitan”. Journal of Advance Microbiology, 18(2):1-8.

[19] Hegarty JP, Dowd MT, Baker KH, " Occurrence of Helicobacter pylori in surface water in the United States”. Journal of Applied Microbiology ,87, 1999, pp.697-701.

[20] Higuer V ," Peptic Ulcer", Healthline, 1(1), 2005, pp. 3-5.

[21] Ishaleku D, Ihiabe H, "Seroprevalence of Helicobacter pylori infection among students of a Nigerian University". Asian Pacific Journal of Tropical Medicine , 3,2010, pp. 584-585 [DOI: 10.1016/S1995-7645(10)60142-3]

[22] Jemikalajah DJ, Okogun GR, "Health point Prevalence of Helicobacter pylori in Central Hospital Warri, Nigeria" African. Journal of Cellular Pathology, 3,2014, pp.57-60

[23] Kanbay M, Gur G, Arslan H, "The relationship of ABO blood group, age, gender, smoking and Helicobacter pylori infection". Digest Disease Science, 50, 2005, pp.1214- 1217

[24] Lyudmila B, "Epidemiology of Helicobacter pylori infection". Horizon Scientific Press, 2015, pp. 278. Available at: http://www.horizonpress.com/helicobacter

[25] Malaty HM, Graham DY, "Importance of childhood socio- economic status on the current prevalence of Helicobacter pylori infection". Gut; 35, 1994, pp.742-745.

[26] Malfertheiner P, Megraud F, O'Morain C, Bazzoli F, El-Omar E, Graham $\mathrm{D}$, et al," Current concepts in the management of Helicobacter pylori infection": the Maastricht III Consensus Report. Gut. 56(6), 2007, pp.772781. This article on Pub Med

[27] Mathewos B, Moges B, Dagnew M, "Seroprevalence and trend of Helicobacter pylori infection in Gondar University Hospital among dyspeptic patients, Gondar, North West Ethiopia". BMC Research Notes.,6, 2013, pp.346.

[28] Malu AO, Ani AE, Bello SS "The prevalence of Helicobacter pylori in dyspeptic patients from the Jos Plateau, Nigeria". Nigeria Medical Journal,41, 2000, pp.1-3.

[29] Megraud F, Bessede E, Lehours P, "Diagnosis of Helicobacter pylori infection". Helicobacter, 19, 2014, pp. 6-10.

[30] Moayyedi P, Axon AT, Feltbolwer R, "Relation of adult lifestyle and socioeconomic factors to the prevalence of Helicobacter pylori infection" International Journal of Epidemiology, 31, 2002, pp.624-631.

[31] Mynepalli SKC, Maureen O,Mumuni A., "Prevalence of Helicobacter pylori and Hygiene Practices among Public Secondary School Students in Ikeja Local Government Area". Health, 6(4), 2014, pp.250-258 
[32] National Population Census (2015). Projected population, 2015-2020. Abuja: National Population Commission Office.

[33] Nurgalieva ZZ, Malaty HM, Graham DY, Almuchambetova R , Machmudova A ,Kapsultanova D, et al, "Helicobacter pylori infection in Kazakhstan: Effect of water source and household Hygiene". America Journal of Tropical Medical and Hygiene, 67, 2002, pp.201-206.

[34] Nwodo EN, Yakubu SE ,Jatau ED , Yabaya A, "Seroprevalence of Helicobacter pylori Infection in Patients with Gastritis and Peptic Ulcer Disease in Kaduna."African Journal of Basic and Applied Sciences, 1(5-6), 2009, pp.123-128.

[35] Obiajuru, IOC, Adogu POU ,"Prevalence of Helicobacter pylori and other intestinal parasites amongst duodenal and gastric ulcer patients at Imo state University Teaching Hospital, Orlu, south-eastern Nigeria". Journal of Medical Science ,4, 2013, pp. 362-369.

[36] Olokoba A.B, Gashau W, Bwala S, Adamu A, Salawu FK, Heli- cobacter pylori infection in Nigerians with dyspepsia. Ghana Medical Journal.41, 2013, pp.79-81.

[37] Oluwasola AO, Ola SO, Saliu L, Solanke TF, Helicobacter pylori infection in South Nigerians: a serological study of dyspeptic patients and healthy individuals". West Africa Journal Medicine, 21(2), 2013, pp.138141. This article on Pub Med

[38] Ophori EA, Isibor C , Onemu SO, Johnny EJ ," Immunological response to Helicobacter pylori among healthy volunteers in Agbor, Nigeria". Asian Pacific Journal of Tropical Disease. 1, 2011, pp. 38-40

[39] Perez-Perez GI, Rothenbacher D , Brenner H," Epidemiology of Helicobacter pylori infection". Helicobacter,9(Suppl. 1): 2004, pp.1-6

[40] Ramin N, Mehrdad S, Mohammad R F , Amirreza D, Laleh M, "Prevalence of Helicobacter pylori in Patients with Dyspepsia". Jundishapur Journal of Microbiology. 7(9), 2014, pp.12676.

[41] Secka O, Antonio M, Tapgun M, Berg DE, Bottomley C, Thomas V., et al "PCR- based genotyping of Helicobacter pylori of Gambian children and adults directly from biopsy specimens and bacterial cultures". Gut Pathogen, 3, 2011, pp.5.

[42] Shi R, Xu. S., Zhang, H., Ding, Y., Sun, G., Huang, X., et al, “ Prevalence and risk factors for Helicobacter pylori infection in Chinese populations". Helicobacter, 13,2008, pp.157-165.

[43] Shmuely H, Obure S, Passaro D, Abuksis G, Yahav J, Fraser G, Pitlik S, Niv Y, "Dyspepsia symptoms and Helicobacter pylori infection, Nakuru, Kenya”. Emerging Infectious Diseases, 9, 2003, pp.1103-1107.

[44] Suerbaum S, Michetti P, "Helicobacter pylori infection". North England Journal Medicine, 347 (15), 2002, pp.1175- 1186. This article on Pub Med.

[45] Tadesse T, Mulugeta G, Shimelis T, "Evaluation of SD Bioline rapid antibody test for diagnosis of Helicobacter pylori infection". Journal of Medical Laboratory and Diagnosis, 4(5), 2013, pp.62-66.
[46] Taiwo T, Ajiboye Edward D, Jatau Helen, Inabo I , "Seroprevalence of Helicobacter pylori infection in patients with non-ulcer dyspepsia in Zaria metropolis". International journal of Scientific and Research Publications, 6.(5). 2018, pp.1-2.

[47] Tijjani B, Umar, A, "Peptic Ulcer Disease and Helicobacter Infection at Kano ,Nigeria”. The Internet Journal of Gastroenterology 8(1), 2018, PP.14.

[48] wikipedia.org/wiki/Karshi_Abuja,

[49] www.distancesfrom.com,https://en

\section{AUTHORS}

First Author - Okezie Gabriel Chidiebere., Department of Medical Laboratory Science, Faculty of Health Sciences and Technology, College of Health Sciences, Nnamdi Azikiwe University, Nnewi Campus, Anambra, State, Nigeria., Email:okeziegc500@gmail.com,Phone number: +2348169706208

Second Author - .Prof. R.A.U.NWOBU, Professor of Medical Microbiology, Department of Medical Laboratory Science, Faculty of Health Sciences and Technology, College of Health Sciences, Nnamdi Azikiwe University, Nnewi Campus, Anambra, State, Nigeria.

Third Author - MGBOWULA GOODNESS IFEOMA (MGBOWULA GOODNESS.I), Digital Health Studies, Algonquin College, Canada., Email:

ifeomagoodness@ymail.com

CORRESPONDING AUTHOR : OKEZIE GABRIEL CHIDIEBERE (OKEZIE, GABRIEL. C), Department of Medical Laboratory Science, Faculty of Health Sciences and Technology, College of Health Sciences, Nnamdi Azikiwe University, Nnewi Campus, Anambra, State, Nigeria., Email:okeziegc500@gmail.com

Phone number: +2348169706208 